\title{
Prevalence, Genotyping, and Seasonality of Rotavirus in Environmental Water Samples and Stool Samples of Gastroenteritis Children in Egypt (2010-2016)
}

\section{Shaheen MNF*}

Environmental Virology Laboratory, Water Pollution Research Department, Environmental Research Division, National Research Centre. Al-Buhouth Street, 12622

Dokki, Giza, Egypt

\section{Research Article}

Volume 3 Issue 1

Received Date: January 18, 2019

Published Date: February 07, 2019

*Corresponding author: Mohamed NF Shaheen, Environmental Virology Laboratory, Water Pollution Research Department, Environmental Research Division, National Research Centre, Egypt, Tel: +2 01016710071; Email: m_nrc2007@yahoo.com

\section{Abstract}

Rotavirus group A (RVA) infection is the most important pathogen of acute diarrheal illness in children and the distribution of this virus in the environment represents threats to Public Health. The aim of the current study was to assess the presence, genotyping, and seasonality of rotavirus in the Egyptian environment and diarrheal specimens of Egyptian children ( $<$ five years of age) with acute gastroenteritis to understand the current status of RVA vaccines and future considerations. In the current study, articles contained data on the presence of RVA in clinical and environmental samples published between 2010-2015 were collected. In total, detection of RVA in diarrheal specimens was ranged from $28.3 \%$ to $76.9 \%$ with a median of $37.8 \%$ of analyzed samples. Detection rate of RVA in raw sewage was ranged from $14 \%$ to $68.4 \%$ with a median of $27.8 \%$ while in treated effluent it was ranged from $2.7 \%$ to $21 \%$ with a median of $11.4 \%$. On the other hand, detection rate of rotavirus in raw Nile water samples was ranged from $13.9 \%$ to $52.9 \%$ with a median of $31.2 \%$ whereas in drinking water it was detected in $23.3 \%$, with prevalence rates ranged from $9.7 \%$ and $20.8 \%$ of analyzed samples. Furthermore, RVA G1 and P[4] were the most prevalent genotypes in clinical samples. Also, RVA G1was the most common genotype detected in environmental samples. G3P[8] and G1P[4] were the most common genotypes in clinical samples and environmental samples, respectively, whereas G1P[8] was the second most common genotype in both clinical and environmental samples. Moreover, the highest detection rates of RVA in both clinical and environmental samples were found in cooler months (autumn and winter). The current study provides useful data to policy makers to develop potential strategies to enhance vaccine uptake and overall impact.

Keywords: Gastroenteritis; Environment; Rotavirus; Sewage; Vaccine; Water 


\section{Journal of Infectious Diseases \& Travel Medicine}

\section{Introduction}

Gastroenteritis is an important illness affecting mainly children < five years of age, worldwide [1]. Enteric viruses are a major cause for gastroenteritis [2] and they usually replicate in the gastrointestinal tract where each gram of stool from infected individual can arise viral particles ranging from $10^{5}-10^{13}[3,4]$. Both asymptomatic and symptomatic shed daily a large number of viruses to the sanitary network. Thus, the wastewater considers as one of the major concentrated sources of human enteric viruses in the environment and pollution of other environmental water matrixes (groundwater, rivers, pond water) may be occurred when sanitary network is broken or when untreated/partially treated wastewater is released directly into the environment [5]. Outbreaks and sporadic cases of gastroenteritis are mostly associated to rotavirus, norovirus, astrovirus, and adenovirus which are also significant cause of water-related diseases [3]. Rotavirus, belonging to family Reoviridae, possess 11 segments of double-stranded (ds) RNA genome surrounded by a non-enveloped triple layered icosahedral capsid. Based on the differences in nucleotide sequence of the two outer layers (VP7 and VP4), rotavirus is classified into several $\mathrm{G}$ and $\mathrm{P}$ genotypes [6].

Rotavirus as causative agent for severe gastroenteritis in children is responsible for an estimated 24 million outpatient visits, 114 million episodes of gastroenteritis, 2.4 million hospitalizations, and 450,000 deaths annually in children below 5 years of age, most of which are documented in low-income countries $[7,8]$. Currently, there are two available live oral attenuated vaccines against rotavirus infections: monovalent vaccine (Rotarix, containing human G1P[8] genotype) and pentavalent vaccine (Rotateq, containing G1-G4 and P[8] genotypes), worldwide. Both vaccines are approved by WHO and they have been found to be safe and effective against RVA infections in large-scale clinical trials in Latin America, Asia, Europe, Africa, and the
United States [9].

\section{Materials and Methods}

For the current systematic review, 13 studies contained data on the occurrence of RVA in clinical and/or environmental samples from Egypt and published between 2010-2016 were collected from google scholar, science direct, and PubMed websites with the topic: monitoring/prevalence/ incidence/epidemiology of rotaviruses in clinical/sewage/water/environmental samples. In addition, our collection for clinical studies was limited to studies that met the following two criteria:1) children $<5$ years and 2) the number tested samples $>60$ diarrheal samples. The prevalence, genotyping, and seasonality of rotavirus were extracted from all selected studies and compared.

\section{Results and Discussion}

Group A rotaviruses are a major pathogen of acute diarrhea in children below five years of age [10]. They are widely distributed in environment and are released in large mount in the stool of infected persons [11-13]. There are several cases of water-borne outbreaks due to rotavirus infection [14]. This virus has been isolated in groundwater [15], sewage [16], drinking water [17], and river water $[18,19]$. The current survey aimed to provide better knowledge of rotaviruses epidemiology in the Egyptian environment and children $(<5$ years of age) with acute gastroenteritis.

In the current survey, 13 studies [20-32] contained data on the prevalence of RVA in clinical and environmental samples are included. Among them, eight studies [20-22,25-29] contained data on occurrence of RV in clinical samples, three studies [30-32] contained data on the prevalence of RVA in environmental samples, and two studies $[23,24]$ contained data on both clinical and environmental samples Table 1.

\begin{tabular}{|c|c|c|c|c|c|c|c|c|c|}
\hline \multirow{2}{*}{ Ref. } & \multicolumn{2}{|c|}{ Data on RV in clinical samples } & \multicolumn{2}{c|}{ Data on RV in sewage samples } & \multicolumn{2}{c|}{ Data on RV in water samples } \\
\cline { 2 - 10 } & \multicolumn{2}{|c|}{ Prevalence } & genotyping & Seasonality & \multicolumn{2}{c|}{ Prevalence } & \multicolumn{2}{c|}{ genotyping } & \multicolumn{2}{c|}{ Seasonality } & Prevalence & genotyping Seasonality \\
\hline$[20]$ & $\checkmark$ & - & - & - & - & - & - & - & - \\
\hline$[21]$ & $\checkmark$ & $\checkmark$ & $\checkmark$ & - & - & - & - & - & - \\
\hline$[22]$ & $\checkmark$ & $\checkmark$ & $\checkmark$ & - & - & - & - & - & - \\
\hline$[23]$ & $\checkmark$ & - & - & - & - & - & $\checkmark$ & $\checkmark$ & $\checkmark$ \\
\hline$[24]$ & $\checkmark$ & - & - & $\checkmark$ & - & - & $\checkmark$ & & $\checkmark$ \\
\hline$[25]$ & $\checkmark$ & - & $\checkmark$ & - & - & - & - & - & - \\
\hline$[26]$ & $\checkmark$ & - & - & - & - & - & - & - & - \\
\hline$[27]$ & $\checkmark$ & $\checkmark$ & $\checkmark$ & - & - & - & - & - & - \\
\hline$[28]$ & $\checkmark$ & $\checkmark$ & - & - & - & - & - & - & - \\
\hline
\end{tabular}

Shaheen MNF. Prevalence, Genotyping, and Seasonality of Rotavirus in 


\section{Journal of Infectious Diseases \& Travel Medicine}

\begin{tabular}{|l|l|l|l|l|l|l|l|l|l|}
\hline$[29]$ & $\checkmark$ & - & - & - & - & - & - & - & - \\
\hline$[30]$ & - & - & - & $\checkmark$ & $\checkmark$ & - & - & - & - \\
\hline$[31]$ & - & - & - & $\checkmark$ & - & $\checkmark$ & $\checkmark$ & - & $\checkmark$ \\
\hline$[32]$ & - & - & - & - & - & - & $\checkmark$ & - & $\checkmark$ \\
\hline
\end{tabular}

Table 1: Data extracted from selected literatures.

\begin{tabular}{|c|c|c|c|c|c|c|c|}
\hline \multirow{2}{*}{ Ref. } & \multicolumn{3}{|c|}{ Study characteristics } & \multicolumn{3}{c|}{ Study results } \\
\cline { 2 - 8 } & $\begin{array}{c}\text { Year(s) of } \\
\text { Sample } \\
\text { collection }\end{array}$ & $\begin{array}{c}\text { Duration of sample } \\
\text { collection per month }\end{array}$ & $\begin{array}{c}\text { Age, } \\
\text { years }\end{array}$ & Method & $\begin{array}{c}\text { No. with } \\
\text { AGE }\end{array}$ & $\begin{array}{c}\text { Prevalence of } \\
\text { RV No (\%) }\end{array}$ & Peak Season \\
\hline$[24]$ & $2007-2009$ & 24 & $<5$ & RT-PCR & 220 & $72(32.7)$ & - \\
\hline$[23]$ & $2008-2009$ & 12 & $<5$ & RT-PCR & 120 & $35(29.2) \%$ & Winter \\
\hline$[21]$ & $2010-2012$ & 17 & $<5$ & RT-PCR & 92 & $45(48.9)$ & Winter \\
\hline$[22]$ & $2011-2012$ & 12 & $<2$ & EIA & 197 & $77(39.1)$ & Winter \\
\hline$[20]$ & $2011-2012$ & 12 & $<5$ & RT-PCR & 110 & $35(31.8)$ & Winter \\
\hline$[25]$ & 2012 & 4 & $<5$ & ELISA & 93 & $53(57)$ & - \\
\hline$[26]$ & $2013-2015$ & 18 & $\leq 24$ & RT-PCR & 100 & $37(37)$ & - \\
\hline$[29]$ & $2014-2015$ & 6 & $<5$ & qr R T-PCR & 65 & $50(76.9)$ & - \\
\hline$[27]$ & $2015-2016$ & 12 & $<5$ & ELISA & 119 & $37(31)$ & Spring \\
\hline$[28]$ & $2015-2016$ & 12 & $<5$ & ELISA & 198 & $56(28.3)$ & Spring \\
\hline
\end{tabular}

RT-PCR: reverse transcriptase polymerase chain reaction; qr RT-PCR, quantitative real time RT-PCR; ELISA: enzymelinked immunosorbent assay; EIA: Enzyme immunoassay.

Table 2: Rotavirus detection among Egyptian children with acute gastroenteritis.

As shown in Table 2, ten studies [20-29] from Egypt contained 1314 specimens from children with acute gastroenteritis were tested for the occurrence of RVA by ELIZA and RT-PCR. Rotavirus detection was ranged from $28.3 \%$ to $76.9 \%$ with a median of $37.8 \%$ of diarrheal samples. Similar results from Nigeria were reported by
Japhet, et al. [33] and Uzoma, et al. [34], they found RVA in $34.5 \%$ and $37.1 \%$ of diarrheal specimens, respectively. However, our analysis is lower than those reported by Lyman, et al. [35] and Pang, et al. [36], they detected RVA infection in $17 \%$ and $18 \%$ diarrheal samples, respectively.

\begin{tabular}{|c|c|c|c|c|c|c|c|}
\hline \multirow[b]{2}{*}{ Ref. } & \multicolumn{4}{|c|}{ Study characteristics } & \multicolumn{2}{|c|}{\begin{tabular}{|c|} 
Study results \\
Prevalence of rotavirus \\
n (\%) \\
\end{tabular}} & \multirow[b]{2}{*}{ Seasonality } \\
\hline & $\begin{array}{l}\text { Year(s) of } \\
\text { Sample } \\
\text { collection }\end{array}$ & $\begin{array}{l}\text { Duration of } \\
\text { sample } \\
\text { collection } \\
\text { per month }\end{array}$ & Place & $\begin{array}{c}\text { Number of raw } \\
\text { Nile and drinking } \\
\text { water samples }\end{array}$ & $\begin{array}{l}\text { Raw Nile } \\
\text { water }\end{array}$ & $\begin{array}{c}\text { Drinking } \\
\text { water }\end{array}$ & \\
\hline [23] & 2006- 2008 & 24 & $\begin{array}{c}\text { Meet Khames, Shoha and } \\
\text { Mahalet Damana WTPs }\end{array}$ & $\begin{array}{l}72 \text { Raw Nile water } \\
72 \text { Drinking water } \\
\end{array}$ & $20(27.7)$ & $12(16.6)$ & $\begin{array}{c}\text { autumn and } \\
\text { winter }\end{array}$ \\
\hline [24] & 2007-2009 & 24 & $\begin{array}{c}\text { Meet Khames, Shoha and } \\
\text { Mahalet Damana WTPs }\end{array}$ & \begin{tabular}{|l|}
72 Raw Nile water \\
72 Drinking water \\
\end{tabular} & $38(52.7)$ & $15(20.8)$ & $\begin{array}{c}\text { autumn and } \\
\text { winter }\end{array}$ \\
\hline [31] & $2009-2011$ & 24 & El-Giza WTP & \begin{tabular}{|l|} 
24 Raw Nile water \\
24 Drinking water \\
\end{tabular} & $7(29.2)$ & $3(12.5)$ & $\begin{array}{c}\text { autumn and } \\
\text { winter }\end{array}$ \\
\hline [32] & $2010-2012$ & 24 & \begin{tabular}{|c|} 
Shark El Mansoura, Depo \\
Awam, El Dnabik WTPs
\end{tabular} & $\begin{array}{l}72 \text { Raw Nile water } \\
72 \text { Drinking water }\end{array}$ & $10(13.9)$ & $7(9.7)$ & $\begin{array}{c}\text { autumn and } \\
\text { winter }\end{array}$ \\
\hline \multicolumn{4}{|c|}{ Total } & $\begin{array}{l}240 \text { Raw Nile water } \\
240 \text { Drinking water }\end{array}$ & $75(31.2 \%)$ & $\begin{array}{c}37(15.4 \\
\%)\end{array}$ & \\
\hline
\end{tabular}

Table 3: Prevalence of rotavirus in water samples collected from Water treatment plants. 
As shown in Table 3, four studies [23,24,31,32] contained data on the presence of RVA genome in 480 water samples (240 raw Nile water and 240 drink water samples) by RT-PCR to evaluate of the role environmental water as possible vehicle for transmission of rotavirus. Overall, RVA genome was detected in $23.3 \%$ of all analyzed samples. In raw Nile water, detection rate of RVA was ranged from $13.9 \%$ to $52.9 \%$ with average of $31.2 \%$ of tested samples. In drinking water, detection rates for rotavirus ranged from $9.7 \%$ to $20.8 \%$ with a median of $40 \%$ of analyzed samples. In previous studies conducted in Pakistan and China, RVA was detected in in $9.4 \%$ and $31 \%$ of water samples, respectively $[37,38]$.
Three studies were found during the period 20102015 to contain data on the detection of RVA genomes in 158 wastewater samples (79 raw sewage and 79 treated effluent) by RT-PCR to evaluate of the role inadequately wastewater treatment as source of rotavirus in aquatic environments [24,30,31] Table 4. Overall, RVA genome was detected in $19.6 \%$ of wastewater samples. This finding is lower than those reported by Ruggeri, et al. [39] and Sdiri-Loulizi, et al. [40], which found RVA in $60.4 \%$, $32 \%$, of sewage samples, respectively. However, our result was higher than those reported by Motayo, et al. [41], who detected RVA in $10.3 \%$ of sewage samples.

\begin{tabular}{|c|c|c|c|c|c|c|c|}
\hline \multirow{3}{*}{ Ref. } & \multicolumn{3}{|c|}{ Study characteristics } & \multicolumn{4}{|c|}{ Study results } \\
\hline & \multirow{2}{*}{$\begin{array}{l}\text { Year(s) of } \\
\text { Sample } \\
\text { collection }\end{array}$} & \multirow{2}{*}{$\begin{array}{c}\text { Duration of } \\
\text { sample collection } \\
\text { per month }\end{array}$} & \multirow[t]{2}{*}{ Place } & \multirow{2}{*}{$\begin{array}{c}\text { Number of raw and } \\
\text { treated sewage } \\
\text { samples }\end{array}$} & \multicolumn{2}{|c|}{$\begin{array}{c}\text { Prevalence of rotavirus } n \\
(\%)\end{array}$} & \multirow[t]{2}{*}{ Seasonality } \\
\hline & & & & & Raw sewage & Treated sewage & \\
\hline [30] & $2006-2007$ & 11 & $\begin{array}{c}\text { Zenin, and El } \\
\text { Berka WWTPs }\end{array}$ & \begin{tabular}{|c|}
36 raw sewage \\
36 treated sewage
\end{tabular} & $5(14)$ & $1(2.7)$ & - \\
\hline [24] & 2007-2009 & 24 & $\begin{array}{l}\text { Meet Khames } \\
\text { WWTP }\end{array}$ & $\begin{array}{c}19 \text { raw sewage } \\
19 \text { treated sewage }\end{array}$ & $13(68.4)$ & $4(21)$ & - \\
\hline [31] & $2009-2011$ & 24 & Zenin WWTP & $\begin{array}{c}24 \text { raw sewage } \\
24 \text { treated sewage }\end{array}$ & $4(16.7)$ & $4(16.7)$ & $\begin{array}{l}\text { autumn and } \\
\text { winter }\end{array}$ \\
\hline \multicolumn{4}{|c|}{ Total } & $\begin{array}{l}79 \text { raw sewage } \\
79 \text { treated sewage }\end{array}$ & $22(27.8)$ & $9(11.4)$ & - \\
\hline
\end{tabular}

Table 4: Prevalence of rotavirus in wastewater samples collected from wastewater treatment plants.

In the current study, RVA detection rate in raw sewage was ranged from $14 \%$ to $68.4 \%$ with a median of $27.8 \%$ whereas RVA detection rate was ranged from $2.7 \%$ to $21 \%$ with a median of $11.4 \%$ of treated effluent samples (Table 4). This result is lower than those detected by Dubois, et al. [42], who detected RVA genomes in $42 \%$ and $67 \%$ of raw sewage and treated effluent samples, respectively. In Iran, RVA genomes were also detected in $73.33 \%$ and $26.67 \%$ of raw sewage and treated effluent samples [43]. Also, He XQ, et al. [44] found RVA in $100 \%$ of raw sewage samples and $90 \%$ of treated sewage samples. Differences in prevalence rates of the current survey as compared to other studies may be occurred due to the differences in the methods used for concentration and detection of RVA. In addition to the differences in the number of tested samples with geographical area and the level of economic status.

Although the current survey was limited to studies published between 2010-2016, however clinical sample collections were started from 2007-2016 whereas environmental sample collections were started from 2006-2012. Based on the periods of sample collections we classified the current survey into different periods using single or combined studies as follows: the prevalence of RVA gastroenteritis were shown during 2007-2009 [23,24], 2010-2012 [20-22,25], 2013-2015 [26,29], 2015$2016[27,28]$ whereas RVA genome in sewage was shown during 2006-2007 [30], 2007-2009 [24], and 2009-2011 [20] and RVA genome in water was shown during 20062008 [23], 2007-2009 [24], 2009-2011 [31], and 20102012 [32]. Our results demonstrated that the higher prevalence of rotavirus infections (55.8\%) among children was found in the diarrheal specimens collected during the period 2013-2015 whereas the higher detection rates of RVA in both wastewater $(44.7 \%)$ and water (36.8\%) samples were found in samples collected during the period 20017-2009, which could be a result of differences in the time of sample collection.

For rotavirus genotyping, two studies [23,28] contained data on RVA G types in 85 environmental and clinical samples. In total, G1, G3, G4, G9, and G10 were the circulated $\mathrm{G}$ serotypes in both environmental and clinical samples, with G1 being the most prevalent (24\%), followed by G3 (18\%), mixed G types (13\%), then G9 and G10 (3.5\%), and G4 (1.2\%) of all analyzed samples (data not shown). On the other hand, one study [23] contained 
data on the presence of $\mathrm{P}$ serotypes in 30 environmental samples where $\mathrm{P}[4], \mathrm{P}[6]$, and $\mathrm{P}[8]$ the circulated $\mathrm{P}$ types among children with acute diarrhea, with $\mathrm{P}[4]$ being the most common P types (56.7\%) followed by P[8] (33.3\%), and $\mathrm{P}[6]$ (10\%) (data not shown). In agreement with the current observation, G1 was the most common circulating genotype in both environmental and clinical samples $[36,39,43,45]$. Also, P[4] was the predominant rotavirus genotype in urban Karen environmental samples, Kenya [46].

Figure 1: Distribution of RVA G-P combination genotypes in environmental and clinical samples by study; total number of environmental samples $=33$ and total number of clinical samples $=212$.

For frequencies of $\mathrm{G}$ and $\mathrm{P}$ combinations in this study, two studies $[23,30]$ contained data on $\mathrm{G} / \mathrm{P}$ combinations in 33 environmental samples whereas four studies $[21,22,25,27]$ contained data on G/P combinations in 212 clinical samples. In Environmental samples, G1P[4] was the most prevalent genotype (39.4\%), followed by G1P[8] (18\%). G1P[6], G3P[4], and G3P[8] genotypes were detected in similar percentage (9\%) and also G2P[8], G9P [8], G12P[4] genotypes, partially typed, and nontypeal samples were equally distributed in $3 \%$ of tested samples (Figure 1). In agreement with previous study from Nigeria, G1P[4] was the most circulated genotype in environmental samples [41]. In clinical samples of current survey, G3P [8] was the most circulated genotype among children with acute diarrhea (27.8\%), followed by G1P[8] (20.7\%), G9P[8] (10.8\%), G2P[4] (7\%), G1P[4] (6\%), and G3P[6] (5\%). Uncommon genotypes with detection rates lower than 5\% were G1P[6] (4\%), mixed genotypes (4\%), G9P[6] (2.8\%), G12P[6] (2.8\%), G4P[8] (3.3\%), no-typeal (2.8\%), G3P[4] (0.9\%), G4P [4] (0.5\%), and G6P[14] (0.5\%) among children with acute gastroenteritis (Figure 1).
Similar finding was reported by Shoeib, et al. [22] and $\mathrm{Li}$, et al. [47], which documented that G3P[8] was the most circulated genotype among children with acute diarrhea.

Collectively, G3P[8] and G1P[4] were the most common genotypes in clinical samples and environmental samples, respectively, this difference may be attributed to the differences in the time and area of collection of clinical and environmental samples. However, G1P[8] was the second most common genotypes in both clinical and environmental samples which agree with other previous studies [47]. In comparison with study conducted in Saudi Arabia, G1P [8] (44\%) was the most prevalent genotype among children with acute diarrhea, followed by G2P[4], G9P[8], G12P[8], and G3P[8] [48]. In study from Nigeria, G3P[6] (24.5\%) was the most common genotype, followed by G1P[6] (12.2\%) and G12P[8] (10.2\%) of the diarrheal samples, respectively [34]. Kittigul, et al. [49] reported that the most common genotype was G1P[8] (27\%), followed by G2P[4], G3P[8], and G9P[8] of diarrheal specimens collected from Thailand. 


\section{Journal of Infectious Diseases \& Travel Medicine}

Based on the current data, the both vaccines (Rotarix and Rotateq) seem to be effective against RVA infections in Egypt. However, updating vaccine formulation are required to contain other circulating genotypes (such as G9 and G10, G1P[4], G2P[4], and G3P[8], and G9P[8]) in our community. Furthermore, most of the included studies [21-24,27,28,31,32] demonstrated that the peak of incidence of rotavirus in both clinical and environmental samples was occurred in cooler months (autumn and winter), which agree with other studies $[43,45]$. It has been suggested that survival of infectious $\mathrm{RV}$ is increased in cooler months with low relative humidity, where this relative drop in humidity and the relatively dry soil moisture combined with rainfall can lead to increase the aerial transport of contaminated fecal and dried materials $[50,51]$.

\section{Conclusion}

The current study provides important data on the circulated rotavirus serotypes in the Egyptian environment and responsible for sever gastroenteritis in our community and therefore the data of the current research can help us in evaluation the efficacy of current RVA vaccines in order to protect our community against all currently distributed rotavirus strains. Future studies including both clinical and environmental samples collected from different arears and for long periods are required for molecular characterization and sequencing of rotavirus strains in the environment and population to evaluate the efficacy of the current vaccines.

\section{References}

1. Lanata CF, Fischer-Walker CL, Olascoaga AC, Torres CX, Aryee MJ, et al. (2013) Global causes of diarrheal disease mortality in children, 5 years of age: a systematic review. PLoS ONE 8(9): e72788.

2. Oude Munnink BB, Van der Hoek L (2016) Viruses causing gastroenteritis: the known, the new and those beyond. Viruses 8(2): 42 .

3. Bosch A, Guix S, Sano D, Pintó RM (2008) New tools for the study and direct surveillance of viral pathogens in water. Curr Opin Biotechnol 19(3): 295301.

4. Espinosa AC, Mazari-Hiriart M, Espinosa R, MaruriAvidal L, Méndes E, et al. (2008) Infectivity and genome persistence of ro- Infectivity and genome persistence of rotavirus and astrovirus in groundwater and surface water. Water Res 42(1011): 2618-2628.

5. Fong TT, Lipp EK (2005) Enteric viruses of human and animals in aquatic environments: heath risks, detection and potential water quality assessment tools. Microbiol Mol Biol Rev 69(2): 357-371.

6. Estes MK, Greenberg HB (2013) Rotaviruses. In: Knipe D Howley P, (Eds.), Fields virology, Lippincott Williams and Wilkins, Philadelphia (PA) 2: 13471401.

7. Glass RI, Kilgore PE, Holman RC, Jin S, Smith JC, et al. (1996) The epidemiology of rotavirus diarrhea in the United States: surveillance and estimates of disease burden. J Infect Dis 1: 5-11.

8. Tate JE, Burton AH, Boschi-Pinto C, Steele AD, Duque J, et al. (2008) estimate of worldwide rotavirusassociated mortality in children younger than 5 years before the introduction of universal rotavirus vaccination programmes: a systematic review and meta-analysis. The Lancet infectious diseases12(2): 136-141.

9. PATH (2018) Rotavirus disease and vaccines in Asia. Vaccine Access and Delivery 2014.

10. Parashar UD, Gibson CJ, Bresee JS, Glass RI (2006) Rotavirus and severe childhood diarrhea. Emerging Infectious Diseases 12: 304-306.

11. De Donno A, Grassi T, Idolo A, Gabutti G, Guido M (2008) The epidemiology of rotavirus infection and the distribution of G-types in Salento (Italy) during 2004-2005. IJHS 1: 26-29.

12. Grassi T, De Donno A, Guido M, Gabutti G (2006) Ggenotyping of rotaviruses in stool samples in Salento, Italy. J Prev Med Hyg 47(4): 138-141.

13. Grassi T, De Donno A, Guido M, Gabutti G (2008) The epidemiology and disease burden of rotavirus infection in the Salento peninsula, "Italy". The Turkish Journal of Pediatrics 50: 132-136.

14. Kittigul L, Khamoun P, Sujirarat D, Utrarachkij F, Chitpirom K, et al. (2001) An improved method for concentrating rotavirus from water samples. Memorias do Instituto Oswaldo Cruz 96(6): 815-821.

15. Abbaszadegan M, Stewart P, Le Chevallier M (1999) A strategy for detection of viruses in groundwater by 


\section{Journal of Infectious Diseases \& Travel Medicine}

PCR. Applied and Environmental Microbiology 65: 444-449.

16. Dubois E, Le Guyader F, Haugarreau L, Kopecka H, Cormier M, et al. (1997) Molecular epidemiological survey of rotaviruses in sewage by reverse transcriptase seminested PCR and restriction fragment length polymorphism assay. Applied and Environmental Microbiology 63: 1794-1800.

17. Gratacap-Cavallier B, Genoulaz O, Brengel-Pesce K, Soule H, Innocenti-Francillard P, et al. (2000) Detection of human and animal rotavirus sequences in drinking water. Applied and Environmental Microbiology 66: 2690-2692.

18. Abad FX, Pintò RM, Bosch A (1998) Flow cytometry detection of infectious rotaviruses in environmental and clinical samples. Applied and Environmental Microbiology 64(7): 2392-2396.

19. Gilgen M, Germann D, Luthy J, Hubner P (1997) Three-step isolation method for sensitive detection of enterovirus, rotavirus, hepatitis A virus, and small round structured viruses in water samples. Int J Food Microbiol 37(2-3): 189-199.

20. El-Senousy WM, Barakat AB, Ghanem HE, Kamel MA (2013) Molecular epidemiology of human adenoviruses and rotaviruses as candidate viral indicators in the Egyptian sewage and water samples. World Applied Sciences Journal 27(10): 1235-1247.

21. Saudy N, Elshabrawy WO, Megahed A, Foad MF, Mohamed A (2016) Genotyping and Clinicoepidemiological Characterization of Rotavirus Acute Gastroenteritis in Egyptian Children. Polish journal of microbiology 65(4): 433-442.

22. Shoeib AR, Hull JJ, Jiang B (2015) Rotavirus G and P types in children with acute diarrhea in Cairo, Egypt, 2011-2012. The Journal of The Egyptian Public Health Association 90(3): 121-124.

23. El-Senousy WM, El-Gamal MS, kamel MM, El-Mahdy ME (2014) Prevalence of Human and Animal Rotaviruses and HEV in Egyptian Nile Water Resources. World Applied Sciences Journal 32(11): 2218-2228.

24. El-Senousy WM, El-Gamal MS, Mousa AA, El-Hawary SE, Fathi MN (2014) Prevalence of Noroviruses among detected enteric viruses in Egyptian aquatic environment. World Applied Sciences Journal 32 (11): 2186-2205.

25. Elnady H, Abdelsamie O, Sallam S, Sherif L, Kholoussi $\mathrm{N}$, et al. (2016) Genotyping of rota virus causing gastroenteritis in Egyptian children. Research Journal of Pharmaceutical, Biological and Chemical Sciences 7(5): 512-521.

26. El-Mosallamy WA, Awadallah MG, El-Fattah A, Diaa M, Aboelazm AA (2015) Human Bocavirus among Viral Causes of Infantile Gastroenteritis. The Egyptian Journal of Medical Microbiology 38(3174): 1-7.

27. Allayeh AK, El Baz RM, Saeed NM, El Sayed M (2018) Detection and Genotyping of Viral Gastroenteritis in Hospitalized Children Below Five Years Old in Cairo, Egypt. Arch Pediatr 6(3): e60288.

28. Shaheen M, El-Daim AS, Hosseney EN, Shoeib AR, Ali MA (2017) Molecular characterization of rotavirus strains causing gastroenteritis in children under 5 years in Cairo, Egypt. MOJ Public Health 6(5): 00187.

29. Ibrahim SB, El-Bialy AA, Mohammed MS, El-Sheikh AO, Elhewala A, et al. (2015) Detection of Rotavirus in children with acute gastroenteritis in Zagazig University Hospitals in Egypt. Electron physician 7(5): 1227 -1233.

30. Kamel AH, Ali MA, El-Nady HG, Aho S, Pothier P, et al. (2010) Evidence of the co-circulation of enteric viruses in sewage and in the population of Greater Cairo. Journal of applied microbiology 108(5): 16201629.

31. El-Senousy WM, Ragab AMES, Handak EMAEH (2015) Prevalence of rotaviruses groups A and C in Egyptian children and aquatic environment. Food environ virol 7(2): 132-141.

32. Osman YA, El-Senousy WM, El-Morsi AA, Rashed MK (2015) Efficiency of Traditional Water Treatment Plant and Compact Units in Removing Viruses. International Journal of Applied Sciences and Biotechnology 3(3): 528-536.

33. Japhet MO, Adesina OA, Famurewa O, Svensson L, Nordgren J (2012) Molecular epidemiology of rotavirus and norovirus in Ile-Ife, Nigeria: High prevalence of G12P[8] rotavirus strains and detection of a rare norovirus genotype. J Med Virol 84(9): 14891496. 


\section{Journal of Infectious Diseases \& Travel Medicine}

34. Uzoma EB, Chukwubuikem C, Omoyibo E, Tagbo O (2016) Rota virus genotypes and the clinical severity of Diarrhoea among children under 5 years of age. Nigerian Postgraduate Medical Journal 23(1): 1-5.

35. Lyman WH, Walsh JF, Kotch JB, Weber DJ, Gunn E, et al. (2009) Prospective study of etiologic agents of acute gastroenteritis outbreaks in child care centers. The Journal of pediatrics 154(2): 253-257.

36. Pang XL, Lee B, Boroumand N, Leblanc B, Preiksaitis $\mathrm{JK}$, et al. (2004) Increased detection of rotavirus using a real time reverse transcription-polymerase chain reaction (RT-PCR) assay in stool specimens from children with diarrhea. Journal of medical virology 72(3): 496-501.

37. Ahmad T, Arshad N, Adnan F, Zaidi NU, Shahid MT, et al. (2016) Prevalence of rotavirus, adenovirus, hepatitis A virus and enterovirus in water samples collected from different region of Peshawar, Pakistan. Ann Agric Environ Med 23(4): 576-580.

38. Yang M, Qiu W, Shen Y, Wu M (2011) Detection of rotaviruses in river water and sewage water in Shanghai by RT-PCR. IEEE, pp: 1.

39. Ruggeri FM, Bonomo P, Ianiro G, Battistone A, Delogu $\mathrm{R}$, et al. (2015) Rotavirus genotypes in sewage treatment plants and in children hospitalized with acute diarrhea in Italy in 2010 and 2011. Applied and environmental microbiology 81(1): 241- 249.

40. Sdiri-Loulizi K, Hassine M, Aouni Z, Gharbi-Khelifi H, Chouchane S, et al. (2010) Detection and molecular characterization of enteric viruses in environmental samples in Monastir, Tunisia between January 2003 and April 2007. Journal of applied microbiology 109(3): 1093-1094.

41. Motayo BO, Faneye A, Adeniji JA (2018) Molecular characterization of group A rotavirus in sewage effluent from Nigeria. International Journal of Infectious Diseases 73: 366.

42. Dubois E, Le Guyader F, Haugarreau L, Kopecka H, Cormier M, et al. (1997) Molecular epidemiological survey of rotaviruses in sewage by reverse transcriptase seminested PCR and restriction fragment length polymorphism assay. Applied and environmental microbiology 63(5): 1794-1800.

43. Kargar M, Javdani N, Najafi A, Tahamtan Y (2013) First molecular detection of group A rotavirus in urban and hospital sewage systems by nested-RT PCR in Shiraz, Iran. Journal of Environmental Health Science and Engineering 11(1): 4.

44. He XQ, Cheng L, Li W, Xie XM, Ma M, et al. (2008) Detection and distribution of rotavirus in municipal sewage treatment plants (STPs) and surface water in Beijing. Journal of Environmental Science and Health Part A 43(4): 424-429.

45. Maneekarn N, Ushijima H (2000) Epidemiology of rotavirus infection in Thailand. Pediatrics international 42(4): 415-421.

46. Kiulia NM, Netshikweta R, Page NA, Van Zyl WB, Kiraithe MM, et al. (2010) The detection of enteric viruses in selected urban and rural river water and sewage in Kenya, with special reference to rotaviruses. Journal of applied microbiology 109(3): 818-828.

47. Li D, Gu AZ, Zeng SY, Yang W, He M, et al. (2011) Monitoring and evaluation of infectious rotaviruses in various wastewater effluents and receiving waters revealed correlation and seasonal pattern of occurrences. Journal of applied microbiology 110(5): 1129-1137.

48. Kheyami AM, Nakagomi T, Nakagomi O, Dove W, Hart CA, et al. (2008) Molecular epidemiology of rotavirus diarrhea among children in Saudi Arabia: first detection of G9 and G12 strains. Journal of clinical microbiology 46(4): 1185-1191.

49. Kittigul L, Swangsri T, Pombubpa K, Howteerakul N, Diraphat P, et al. (2014) Rotavirus infection in children and adults with acute gastroenteritis in Thailand. Southeast Asian Journal of Tropical Medicine and Public Health 45(4): 816.

50. Moe K, Shirley JA (1982) The effects of relative humidity and temperature on the survival of human rotavirus in faeces. Arch Virol 72: 179-186.

51. Ansari SA, Springthorpe VS, Sattar SA (1991) Survival and vehicular spread of human rotaviruses: possible relation to seasonality of outbreaks. Rev Infect Dis 13(3): 448-461. 